\title{
LOSS OF WATER AND NUTRIENTS IN DIFFERENT SOIL TILLAGE SYSTEMS SUBJECTED TO NATURAL RAINFALL IN THE STATE OF MATO GROSSO, BRAZIL
}

\author{
Marcelo H. S. Leite ${ }^{*}$, Eduardo G. Couto², Ricardo S. S. Amorim², José F. Scaramuzza² \\ ${ }^{1 *}$ Corresponding author. Universidade Federal de Mato Grosso (UFMT)/ Cuiabá - MT, Brasil. E-mail: sleitebrum@gmail.com
}

\section{KEYWORDS}

laminar runoff, losses of nutrients, losses of potassium $(\mathrm{K})$, transports nutrients, water erosion.

\begin{abstract}
The aim of this study was to evaluate the loss of water and nutrients by laminar runoff in different soil tillage systems subjected to natural rainfall. Five experimental plots were established for the cultivation of cotton in the city of Campo Verde - MT, with the following treatments: CTDP $=$ conventional soil tillage and planting of the cotton in the direction of the slope; $\mathrm{CTCP}=$ conventional tillage and contour planting; $\mathrm{CP}=$ tillage of soil with a disk harrow and a leveling harrow, followed by contour planting; $\mathrm{CoP}=$ tillage by two passes of a leveling harrow followed by contour planting; $\mathrm{MTCP}=$ minimum tillage with contour planting. The losses of water by laminar runoff in were determined by the stored volume and samples were taken to quantify nutrient losses in water (nitrite, nitrate, phosphate and potassium). The losses of water by runoff were highest for the CTDP; intermediate for the treatments CTCP, CoP and MTCP, and lowest for the CP. Potassium $(\mathrm{K})$ was the nutrient that had the highest concentrations and losses in water: the highest values were found in the CTDP and CTCP tillage systems, whereas the lowest were observed for the CP, CoP, and MTCP treatments. The concentrations and the losses by water erosion of phosphate $\left(\mathrm{PO}_{4}{ }^{3-}\right)$, nitrite $\left(\mathrm{NO}_{2}^{-}\right)$, and nitrate $\left(\mathrm{NO}_{3}{ }^{-}\right)$were low in all of the soil tillage systems compared to the losses of $\mathrm{K}$ in this study.
\end{abstract}

\section{INTRODUCTION}

Water erosion transports nutrients, some at high concentrations, in solution and adsorbed onto sediments, which causes problems related to the depletion of agricultural soils and eutrophication of surface waters. According to the study of Klimaszyk et al. (2015), runoff significantly affects the chemistry of a lake, which suggests that the gradual replacement of monocultures is likely to increase the nutrient load for fresh surface waters.

Studies involving different soil management systems, Bertol et al. (2007) and Tartari et al., 2012, reported that soil losses were more influenced by management systems than were water losses. Some studies (Ramos et al., 2014b; Luciano et al., 2009) have shown that water losses due to water erosion have the same tendency as soil losses but with smaller differences between treatments. Similar losses have even been reported to occur among the different soil tillage methods (Bertol, 1994) depending on conditions such as rainfall, soil type, topography, and the crop succession/rotation used in the soil management system.
The concentration of a particular nutrient in the runoff water varies mainly with its concentration in the soil, which is influenced by the soil type, fertilization, and type of management used. The total amount of the nutrient transported by water erosion processes depends on its concentration in the eroded material and the total volume of the material lost due to erosion (Munodawafa, 2012).

In the State of Mato Grosso (Brazil), information is lacking for evaluations of water and nutrient losses in the laminar runoff under different types of soil management, as well as the possible impacts these losses may have on the environment. The information available in the literature is often based on the extrapolation of results of studies in other Brazilian states. High concentrations of nutrients - especially nitrogen $(\mathrm{N})$ - in the water can cause damage to the environment and to human and animal health. Phosphorus (P) and $\mathrm{N}$ are essential elements for triggering the eutrophication of water resources; however, $\mathrm{P}$ is considered to be the limiting element because $\mathrm{N}$ can be supplied via the fixation of atmospheric $\mathrm{N}$ by some aquatic plants (Vidal \& Capelo Neto, 2014). In addition to eutrophication, $\mathrm{N}$ may also cause human health problems

${ }^{2}$ Departamento de Solos e Engenharia Rural da Faculdade de Agronomia e Zootecnia da UFMT e Programa de Pós-Graduação em Agricultura Tropical da UFMT/ Cuiabá - MT, Brasil.

Received in: 3-24-2017

Accepted in: 9-18-2018 
such as blue-baby syndrome or methemoglobinemia, which is an alteration of the blood oxygenation due to nitrate- $\mathrm{NO}_{3}{ }^{-}$(Ortiz, 2015).

The quantification of water and nutrient losses in runoff is fundamental for the definition of critical limits of tolerable loss in the cultivated areas in the State of Mato Grosso, which is a predominantly agricultural region, and depending on the soil management, these cultivated areas may be suffering very high losses of water and nutrients. The objective of this study was to evaluate the losses of water and nutrients by runoff in a Typical Acric Redyellow Latosol cultivated with cotton under different soil tillage systems subjected to natural rainfall.

\section{MATERIAL AND METHODS}

The study was developed in five experimental plots, $3.5 \mathrm{~m}$ wide and $11 \mathrm{~m}$ long, set up in the Mourão I Farm (Coord. X: UTM $723135.9 \mathrm{~m}$ and Coord. Y: UTM $8291389.1 \mathrm{~m})$ located in the municipality of CampoVerde, Mato Grosso State, Brazil (Figure 1), in an Typical Acric Red-yellow Latosol with a clayey texture and an average slope of $0.025 \mathrm{~m} \mathrm{~m}^{-1}$. The experimental plots were cultivated with cotton (Gossypium hirsutum), and a notillage seeder was used for the sowing on December 9, 2005 , with a spacing of $0.9 \mathrm{~m}$ between the rows, a density of 10 seeds per linear meter of furrow, and a depth of approximately $0.03 \mathrm{~m}$. The distance between the five plots was approximately $30 \mathrm{~m}$, maintaining sufficient space for the crop management and mechanical fertilization performed by the farm's technical team. The harvesting in the plots was done on June 26, 2006.

Each plot received different soil tillage treatment: 1) conventional tillage (one pass of a disk harrow and two passes of a leveling harrow in the plot) and downhill planting - that is, the planting was done in the direction of the slope (CTDP); 2) conventional tillage and contour planting - planting was done perpendicular to the slope (CTCP); 3) tillage by passing a disk harrow and a leveling harrow over the plot, followed by contour planting $(\mathbf{C P}) ; 4)$ tillage with two passes of a leveling harrow, followed by contour planting (CoP); and 5) minimum tillage and contour planting (MTCP). In this last treatment, the management used on the studied farm was adopted (Table 1).

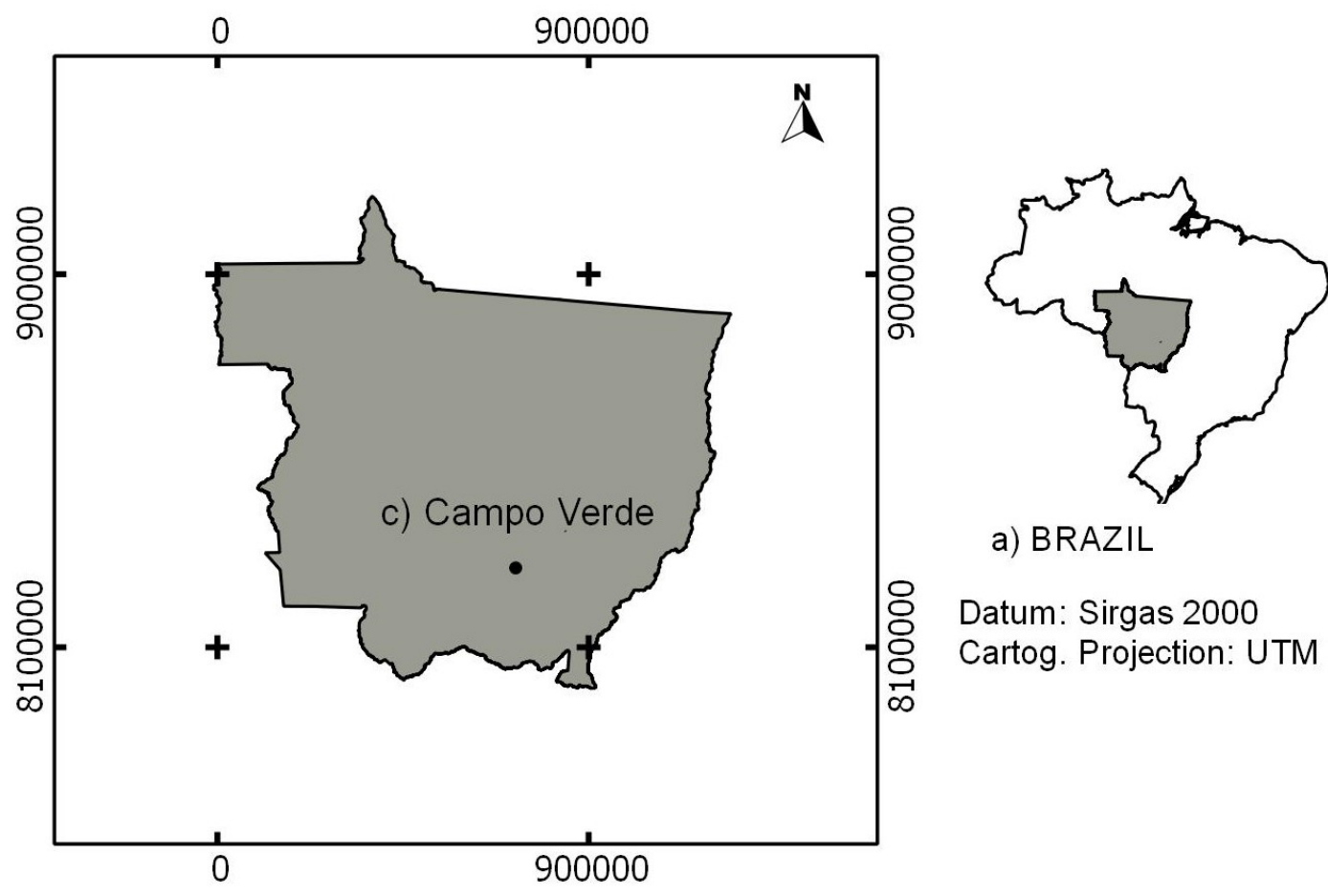

b) STATE OF MATO GROSSO

FIGURE 1. Location of the study area: a) Country—Brazil; b) State—Mato Grosso; and c) Municipality—Campo Verde.

TABLE 1 . History of the area and management practices adopted by the farm (Leite et al., 2009).

\begin{tabular}{|c|c|c|c|c|c|c|c|c|c|}
\hline \multirow[t]{2}{*}{ Harvest } & \multirow[t]{2}{*}{ Crops } & \multirow[t]{2}{*}{ Period } & \multirow[t]{2}{*}{ Agricultural implement } & \multicolumn{6}{|c|}{ Fertilization $\left(\mathrm{kg} \mathrm{ha}^{-1}\right)$} \\
\hline & & & & MAP & $\mathrm{KCl}$ & Urea & $\mathrm{AS}$ & SS & Produbor \\
\hline \multirow{3}{*}{$2005 / 2006$} & Millet & October & $\begin{array}{l}\text { Chain pulled by two tractors (to } \\
\text { incorporate seeds) }\end{array}$ & 100 & 80 & & & 130 & 2 \\
\hline & Cotton & December & & & 140 & & 180 & & \\
\hline & & January & & & & 150 & & & \\
\hline
\end{tabular}

$\mathrm{MAP}=$ monoammonium phosphate, $\mathrm{KCl}=$ potassium chloride, $\mathrm{AS}=$ ammonium sulfate, $\mathrm{SS}=$ single superphosphate, and Produbor $=$ boron 
In the 5 years prior to the establishment of the experiment, the area under study had been managed with the minimum tillage system, using millet (Pennisetum glaucum) as plant cover for the formation of straw, with its seeds distributed by broadcast seeding and then incorporated using a chain pulled by two tractors. The fertilizations for the 2005/2006 crop were performed at three different times: broadcast fertilization at planting (nitrogen, phosphorus, potassium, and boron), done on October 22, 2005; topdressing fertilization (nitrogen and potassium), done 15 days after emergence of the cotton seeds; and, finally, second topdressing nitrogen fertilization (urea), done 50 days after emergence of the cotton seeds (Table 1).

The experimental plots were set up according to the specifications of Wischmeier \& Smith (1978) and were composed of the following parts (Figure 2):

a) Rain catchment area- $-3.5 \mathrm{~m}$ wide and $11 \mathrm{~m}$ long, delimited with $0.25 \mathrm{~m}$ high galvanized sheets, driven $0.10 \mathrm{~m}$ into the ground;

b) Collecting gutter and PVC tube $(100 \mathrm{~mm})$ bottom part of the plot with the function of capturing and transporting the runoff to the collection structure; and

c) Collection structure-positioned at the lower end of the experimental area, composed of a rectangular box of galvanized sheet metal, containing a filter system (geotextile fabric). In this box, there was an outlet consisting of a "Geib" divider, with nine openings (d). The central opening was connected to a drum (e), which stored the runoff water that passed through the 1/9 fraction of the Geib gutter.

The sediments transported by the laminar runoff were retained in a filter (geotextile fabric) that enabled the separation of the larger soil particles. The collections for analysis of nutrient losses in water were done in this structure after the filtration.

The total rainfall in the experimental plots was measured daily by pluviographs from December 2005 to June 2006. The rainfall coefficient (Rc) was calculated for each period between collections (approximately every 15 days), using the mean pluviometric values for the period between collections. The rainfall coefficient was determined by [eq. (1)], as proposed by Lombardi Neto (1977).

$$
R c=\frac{(P m)^{2}}{P a}
$$

Where:

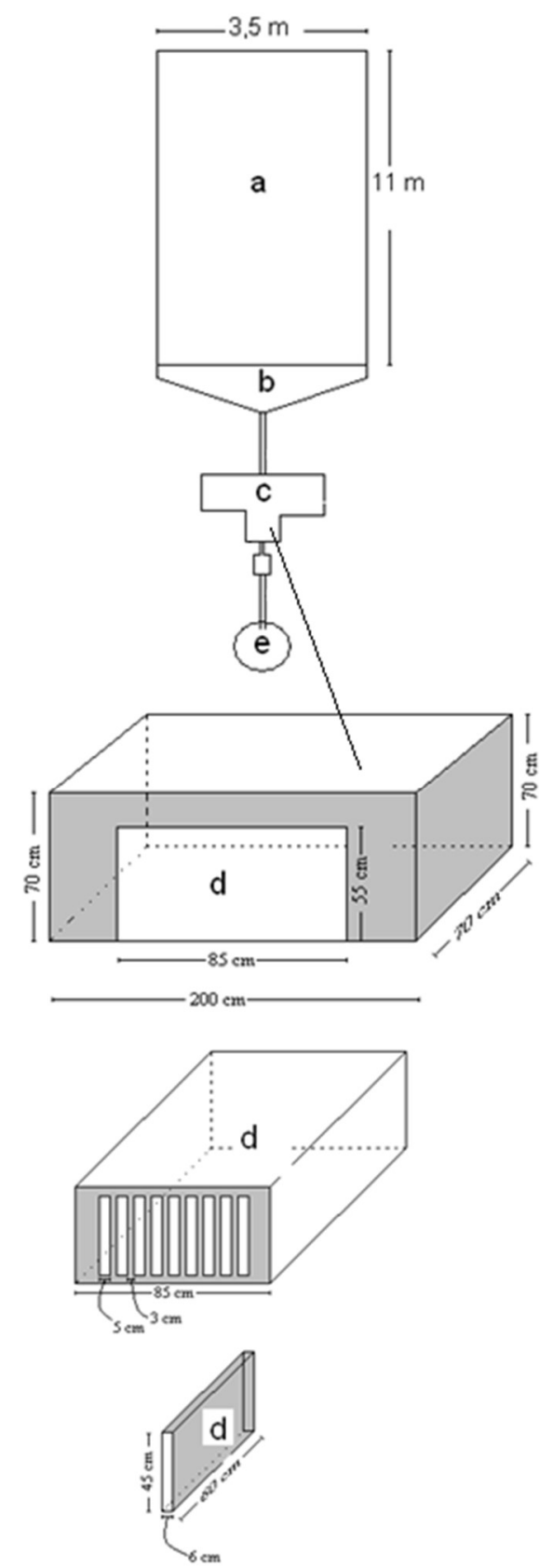

FIGURE 2. Schematic representation of the experimental plot for monitoring water and nutrient loss by runoff: a) rain catchment area, b) collecting gutter, c) collection structure, d) Geib type 1/9 divider, and e) drum for collecting the water

$R c=$ rainfall coefficient for the period between collections;

$P m=$ mean precipitation in the period between collections (mm), and

$P a=$ mean annual precipitation $(\mathrm{mm})$. 
The rainfall erosivity $\left(\mathrm{EI}_{30}\right)$ was determined from pluviometric data based on adjustment of the methodology proposed by Bertoni \& Lombardi Neto (1990), which estimates the $\mathrm{EI}_{30}$ index using the rainfall coefficient (Rc) according to [eq. (2)].

$$
E I=56.115\left(R_{c}\right)^{0.9504}
$$

Where:

$E I=$ mean erosivity index $\left(\mathrm{EI}_{30}\right)$ of the period between collections $\left(\mathrm{MJ} \mathrm{mm} \mathrm{ha} \mathrm{m}^{-1} \mathrm{~h}^{-1}\right.$ ), and

$R_{c}=$ rainfall coefficient of the period between collections.

The values of the parameters (56.115 and 0.9504) from equation (2) were adjusted by Morais et al. (1991) for stations in Cuiabá, Mato Grosso State, Brazil, located 130 $\mathrm{km}$ from the experimental area; these are the closest values at this time for the estimates.

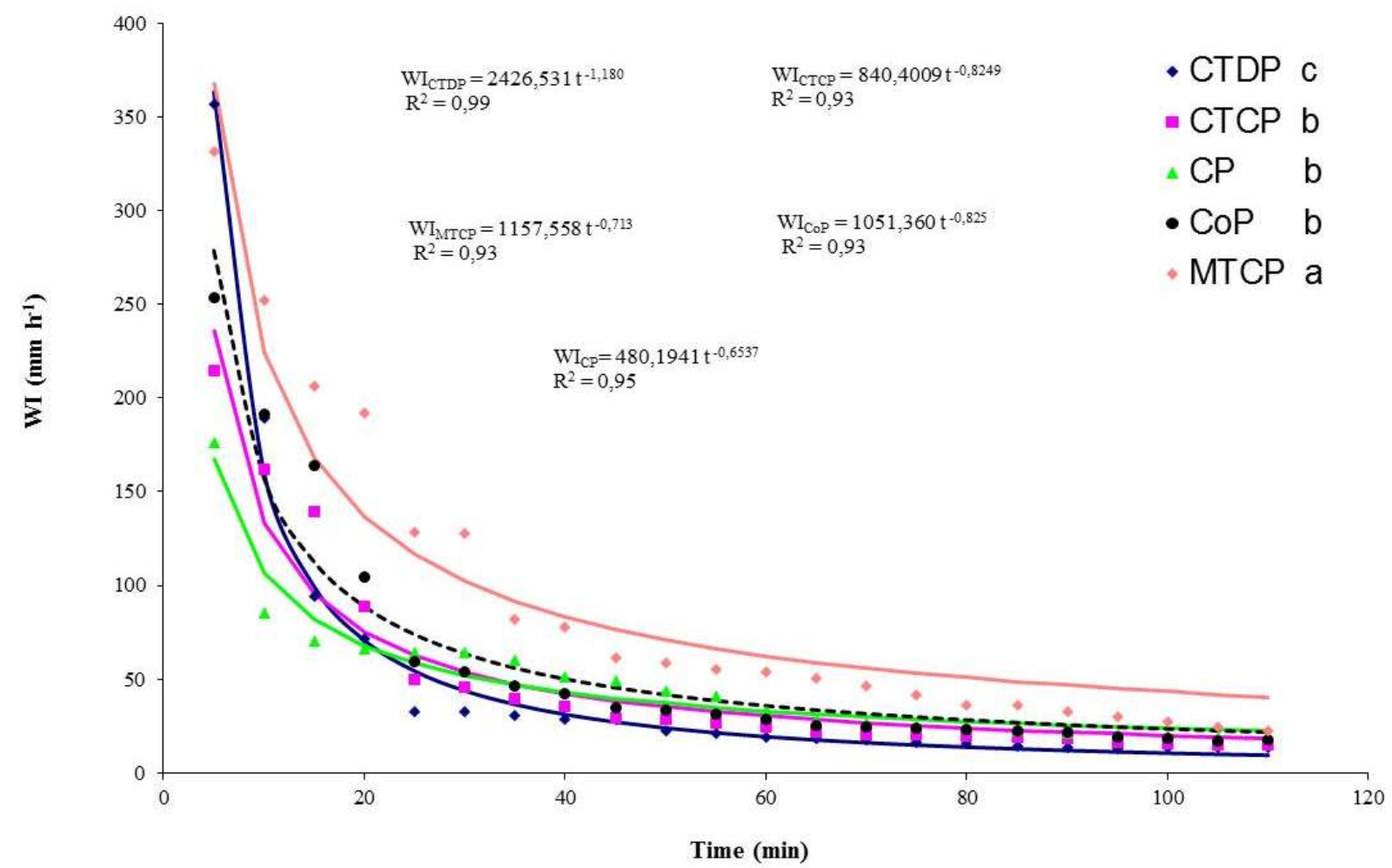

$\mathbf{C T D P}=$ conventional soil tillage and planting of the cotton in the direction of the slope; $\mathbf{C T C P}=$ conventional tillage and contour planting; $\mathbf{C P}=$ tillage of soil with a disk harrow and a leveling harrow, followed by contour planting; $\mathbf{C o P}=$ tillage by two passes of a leveling harrow followed by contour planting; MTCP = minimum tillage with contour planting. Same letters do not differ statistically by the identity testing of models fit to the infiltration rate data $(\mathrm{p}<0.1)$

FIGURE 3. Water infiltration (WI) rate in different soil tillage systems (Leite et al., 2009). characteristics in the different experimental plots in terms of the basic infiltration rate (BIR) included the lowest BIR observed for the CTDP treatment, with a value of 10.50 $\mathrm{mm} \mathrm{h}^{-1}$; intermediate values for the CTCP, CP, and CoP treatments, varying from 20.0 to $23.6 \mathrm{~mm} \mathrm{~h}^{-1}$, and, finally, the highest BIR of $43.5 \mathrm{~mm} \mathrm{~h}^{-1}$ for the MTCP system (Figure 3).

The water loss data obtained in the field were fit to the mean slope of the standard plot $\left(0.09 \mathrm{~m} \mathrm{~m}^{-1}\right)$ using the equation recommended by Wischmeier \& Smith (1978). For the determination of the losses of the nutrients in suspension, $200 \mathrm{~mL}$ of water from the runoff generated per collection period in each plot was collected. The levels of nitrate, nitrite, and phosphate were determined in an ion chromatograph. The levels of potassium were quantified by Mehlich 1 extraction $\left(\mathrm{H}_{2} \mathrm{SO}_{4} 0.025 \mathrm{~N}+\mathrm{HCl} 0.05 \mathrm{~N}\right)$ and determined by flame photometry.

$\mathrm{WI}_{\mathrm{CP}}=480,1941 \mathrm{t}^{-0,653}$

$\mathrm{R}^{2}=0,95$ 
The statistical analysis consisted of model fitting to describe the trends of the losses of water and nutrients from the runoff over time for each treatment (type of soil tillage system). After defining the models, identity testing was done to allow a statistical assessment of the differences among the treatments and their respective variables.

\section{RESULTS AND DISCUSSION}

Considering the total rainfall in the experimental period in the different soil tillage systems, the water losses due to water erosion were very low (Figure 4) - lower than $2,13 \%$ for the conventional tillage and planting done in the direction of the slope. When studying water and nutrient losses by runoff in large vegetable plots under conventional and organic agriculture and in a forest system (control), Ramos et al. (2014a) observed low water losses $(<1 \%)$ compared to the total rainfall during the period studied.

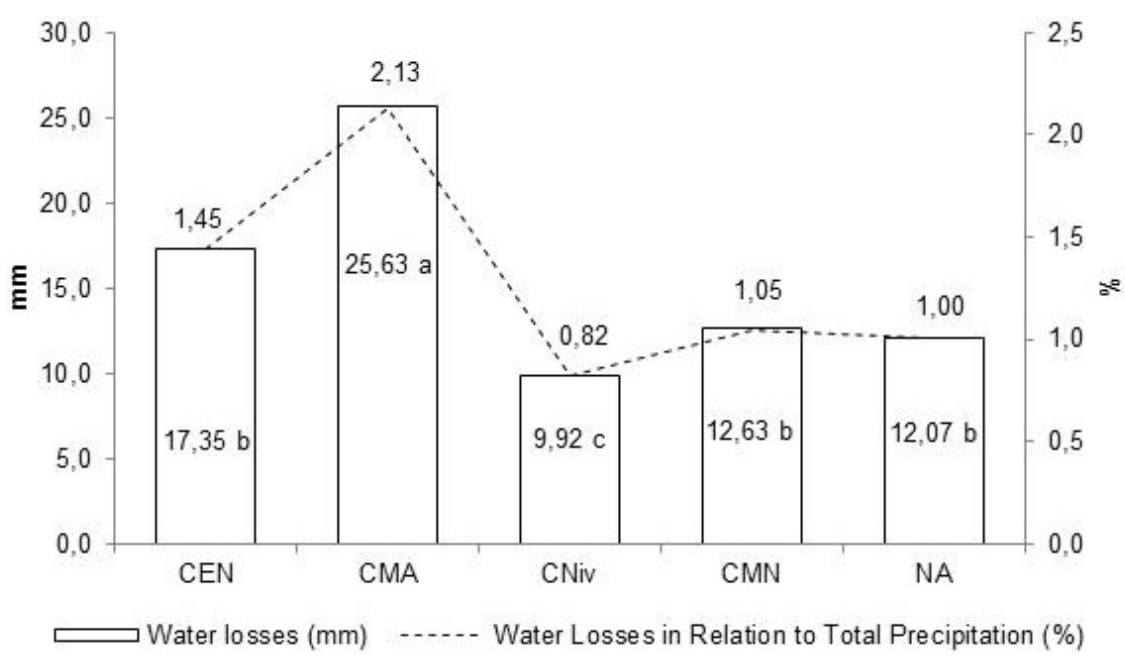

CTDP = conventional soil tillage and planting of the cotton in the direction of the slope; $\mathbf{C T C P}=$ conventional tillage and contour planting; $\mathbf{C P}=$ tillage of soil with a disk harrow and a leveling harrow, followed by contour planting; $\mathbf{C o P}=$ tillage by two passes of a leveling harrow followed by contour planting; $\mathbf{M T C P}=$ minimum tillage with contour planting. Same letters for the total water losses $(\mathrm{mm})$ do not differ between each other for the identity testing of models $(\mathrm{p}<0.05)$.

FIGURE 4. Total water losses (mm) and water losses in relation to the total precipitation (\%).

The differences in the water losses via runoff in the five soil tillage systems studied here allowed the separation of these losses into three groups: the largest in the CTDP tillage, intermediate values in the CTCP, CoP, and MTCP tillage systems, and the smallest in the CP soil tillage. For the losses in the different soil tillage systems, these results agree with those of Panachuki et al. (2015), who found the lowest losses for treatments with the highest mulch densities when studying water losses in the erosion process. Panachuki et al. (2011) reported that the water losses in the different management and soil coverage systems were higher in the soil tillage systems with harrowing and incorporation of the plant cover; however, in direct seeding, without the presence of plant cover, the water losses were higher than those found in the treatments using a harrow.

The largest water loss values in the plot with the CTDP soil tillage system corroborated the results obtained by Marioti et al. (2013), who obtained the largest water loss results for treatments involving sowing in rows in the direction of the slope when evaluating the water and soil losses by water erosion in two sowing directions (sowing in rows in the direction of the slope and sowing in rows perpendicular to the slope).

The variations in the water losses on different sampling dates were similar to those in the rainfall erosivity index $\left(\mathrm{EI}_{30}\right)$ when the same scales and units of measurements of the respective vertical axes (Figure 5) were considered. Among the nutrients lost by laminar runoff, the greatest losses were observed for potassium $(\mathrm{K})$, whereas the amounts of nitrate $\left(\mathrm{NO}_{3}{ }^{-}\right)$, nitrite $\left(\mathrm{NO}_{2}{ }^{-}\right)$, and phosphate $\left(\mathrm{PO}_{4}{ }^{3-}\right)$ lost in water through laminar runoff were low compared to the potassium losses (Figure 5).

Although the losses of phosphate $\left(\mathrm{PO}_{4}{ }^{3-}\right)$ in the runoff were low, an atypical result of $270 \mathrm{~g} \mathrm{ha}^{-1}$ of $\mathrm{PO}_{4}{ }^{3-}$ was observed for the CTDP treatment (Figure 5 a) in collection number $11(04 / 04 / 06)$, which corresponds to $98 \%$ of all the phosphate lost in the period studied. This fact can be explained by the high concentration of the element in the erosion process in this collection (25 times higher than that in all of the previous collections-see Table $2 \mathrm{a})$, combined with the high water loss $(3.40 \mathrm{~mm})$ via runoff on this date (Figure $5 \mathrm{a}$ ), and by the mineral phosphate fertilizations, as shown in Table 1. These results agree with those published by Ramos et al. (2014a), in which high concentrations of phosphorus in the runoff were obtained in a conventional agricultural systemreported by the authors as being due to the large amounts of mineral fertilizers supplied into the system. The lack of plant cover and the planting of the cotton in the direction of the slope (downhill) - a situation to which the CTDP treatment was subjected-decreased the rate of water infiltration in the soil and the surface roughness. In this study, this situation contributed to the increase in the runoff volume and flow rate, causing the high loss of phosphate in this collection. 


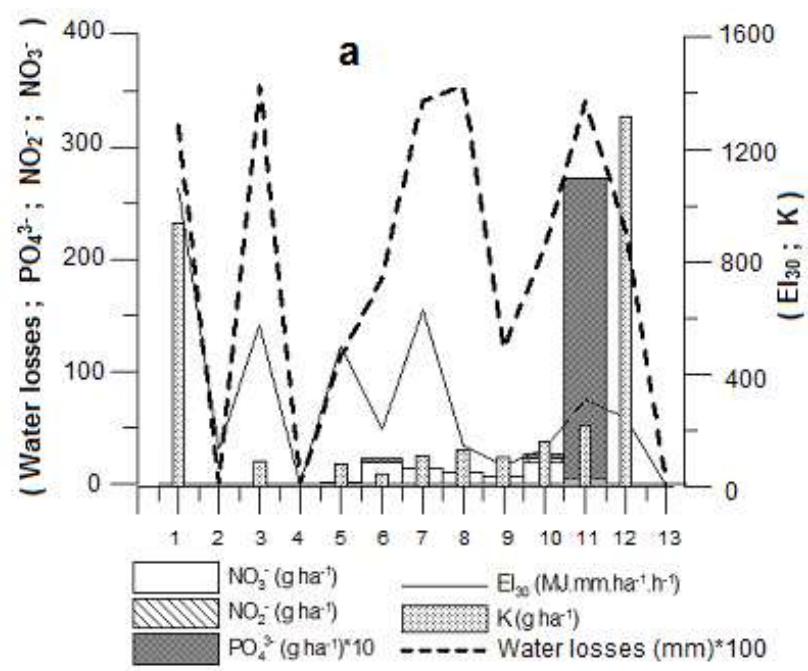

\begin{tabular}{|l|c|}
\hline Number & Sampling dates \\
\hline 1 & 22-Dec-05 \\
\hline 2 & 3-Jan-06 \\
\hline 3 & 12-Jan-06 \\
\hline 4 & 27 -Jan-06 \\
\hline 5 & 10 -Feb-06 \\
\hline 6 & 23-Feb-06 \\
\hline 7 & 5-Mar-06 \\
\hline 8 & 16-Mar-06 \\
\hline 9 & 18-Mar-06 \\
\hline 10 & 23-Mar-06 \\
\hline 11 & 4-Apr-06 \\
\hline 12 & 21-Apr-06 \\
\hline 13 & 20-May-06 \\
\hline
\end{tabular}
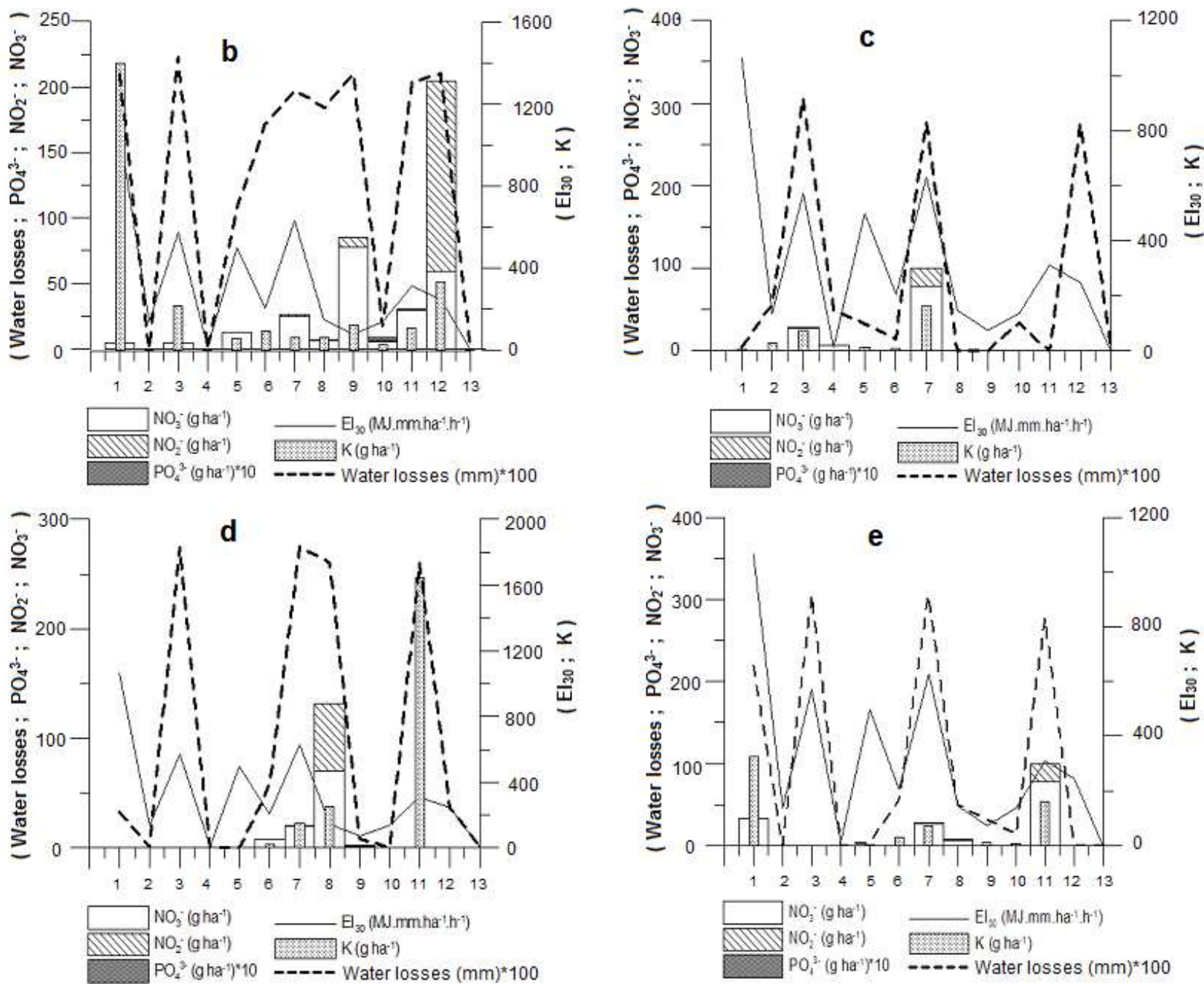

(a) CTDP = conventional soil tillage and planting of the cotton in the direction of the slope; (b) CTCP = conventional tillage and contour planting; (c) $\mathrm{CP}=$ tillage of soil with a disk harrow and a leveling harrow, followed by contour planting; (d) $\mathrm{CoP}=$ tillage by two passes of a leveling harrow followed by contour planting; (e) $\mathrm{MTCP}=$ minimum tillage with contour planting. $\mathrm{NO}_{3}{ }^{-}=$nitrate $^{\mathrm{NO}_{2}}=$ nitrite $^{-} \mathrm{PO}_{4}{ }^{3-}=$ phosphate, and $\mathrm{K}=$ potassium.

FIGURE 5. Rainfall erosivity index $\left(\mathrm{EI}_{30}\right)$ and water and nutrient losses by runoff. 
TABLE 2. Concentrations of the nutrients in the laminar runoff per sampling date.

\begin{tabular}{|c|c|c|c|c|c|}
\hline \multicolumn{6}{|c|}{ Nutrient Concentration $\left(\mathrm{mg} \mathrm{L}^{-1}\right)$} \\
\hline Treat. & D. Sample & $\mathrm{NO}_{2}^{-}$ & $\mathrm{NO}_{3}^{-}$ & $\mathrm{PO}_{4}{ }^{3-}$ & $\mathrm{K}$ \\
\hline \multirow{13}{*}{ a } & $22 / 12 / 05$ & 0 & 0 & 0 & 29,43 \\
\hline & 03/01/06 & 0 & 0,11 & 0 & 0 \\
\hline & $12 / 01 / 06$ & 0 & 0 & 0 & 2,59 \\
\hline & $27 / 01 / 06$ & 0,03 & 0,23 & 0 & 0 \\
\hline & $10 / 02 / 06$ & 0 & 0,13 & 0 & 6,87 \\
\hline & $23 / 02 / 06$ & 0 & 1,04 & 0,17 & 2,59 \\
\hline & 05/03/06 & 0 & 0,43 & 0 & 3,31 \\
\hline & $16 / 03 / 06$ & 0 & 0,28 & 0 & 3,62 \\
\hline & $18 / 03 / 06$ & 0 & 0,53 & 0 & 8,9 \\
\hline & $23 / 03 / 06$ & 0,19 & 0,9 & 0,15 & 7,55 \\
\hline & 04/04/06 & 0 & 0,1 & 7,9 & 6,38 \\
\hline & $21 / 04 / 06$ & 0 & 0 & 0 & 58,37 \\
\hline & $20 / 05 / 06$ & 0 & 0,47 & 0 & 0 \\
\hline \multirow{13}{*}{$\mathrm{c}$} & $22 / 12 / 05$ & 0 & 0 & 0 & 8,07 \\
\hline & 03/01/06 & 0 & 0 & 0 & 0 \\
\hline & $12 / 01 / 06$ & 0 & 0,1 & 0 & 2,48 \\
\hline & $27 / 01 / 06$ & 0 & 0 & 0 & 0 \\
\hline & $10 / 02 / 06$ & 0 & 0 & 0 & 0 \\
\hline & $23 / 02 / 06$ & 0 & 0 & 0 & 4,97 \\
\hline & $05 / 03 / 06$ & 0,21 & 4,43 & 0 & 4,03 \\
\hline & $16 / 03 / 06$ & 0,02 & 0,54 & 0 & 4,03 \\
\hline & $18 / 03 / 06$ & 0,03 & 0,94 & 0,2 & 9,83 \\
\hline & $23 / 03 / 06$ & 0,03 & 0,79 & 0 & 9,62 \\
\hline & $04 / 04 / 06$ & 0,04 & 0,66 & 0 & 6,1 \\
\hline & $21 / 04 / 06$ & 0,55 & 8,42 & 3,9 & 44,14 \\
\hline & $20 / 05 / 06$ & 0 & 0 & 0 & 0 \\
\hline \multirow{13}{*}{ e } & $22 / 12 / 05$ & 0 & 1,51 & 0 & 14,71 \\
\hline & 03/01/06 & 0 & 0 & 0 & 0 \\
\hline & $27 / 01 / 06$ & 0 & 0 & 0 & 0 \\
\hline & $12 / 01 / 06$ & 0 & 0 & 0 & 0 \\
\hline & $10 / 02 / 06$ & 0 & 0,18 & 0 & 9,1 \\
\hline & $23 / 02 / 06$ & 0 & 0,02 & 0 & 5,17 \\
\hline & $05 / 03 / 06$ & 0,04 & 0,87 & 0 & 2,38 \\
\hline & $16 / 03 / 06$ & 0,2 & 1,22 & 0 & 0 \\
\hline & $18 / 03 / 06$ & 0 & 0,08 & 0 & 3,83 \\
\hline & $23 / 03 / 06$ & 0,03 & 0,16 & 0 & 4,86 \\
\hline & $04 / 04 / 06$ & 0,8 & 2,8 & 0 & 5,79 \\
\hline & $21 / 04 / 06$ & 0 & 0 & 0 & 0 \\
\hline & $20 / 05 / 06$ & 0 & 0 & 0 & 0 \\
\hline
\end{tabular}

\begin{tabular}{|c|c|c|c|c|c|}
\hline \multicolumn{6}{|c|}{ Nutrient Concentration $\left(\mathrm{mg} \mathrm{L}^{-1}\right)$} \\
\hline Treat. & D. Sample & $\mathrm{NO}_{2}^{-}$ & $\mathrm{NO}_{3}^{-}$ & $\mathrm{PO}_{4}^{3-}$ & $\mathrm{K}$ \\
\hline \multirow{13}{*}{$\mathrm{b}$} & $22 / 12 / 05$ & 0 & 0,21 & 0 & 66,71 \\
\hline & 03/01/06 & 0 & 0 & 0 & 0 \\
\hline & $12 / 01 / 06$ & 0 & 0,21 & 0 & 9,52 \\
\hline & $27 / 01 / 06$ & 0 & 0 & 0 & 0 \\
\hline & $10 / 02 / 06$ & 0 & 1,19 & 0 & 5,28 \\
\hline & $23 / 02 / 06$ & 0 & 0 & 0 & 5,17 \\
\hline & $05 / 03 / 06$ & 0,08 & 1,27 & 0 & 3,1 \\
\hline & $16 / 03 / 06$ & 0,01 & 0,36 & 0 & 3,31 \\
\hline & $18 / 03 / 06$ & 0,32 & 3,72 & 0 & 5,69 \\
\hline & $23 / 03 / 06$ & 0,45 & 3,32 & 0,12 & 13,65 \\
\hline & 04/04/06 & 0,05 & 1,45 & 0 & 5,28 \\
\hline & $21 / 04 / 06$ & 6,93 & 2,82 & 0 & 15,7 \\
\hline & $20 / 05 / 06$ & 0 & 0 & 0 & 0 \\
\hline \multirow{13}{*}{$\mathrm{d}$} & $22 / 12 / 05$ & 0 & 0 & 0 & 0 \\
\hline & 03/01/06 & 0 & 0,16 & 0 & 7,24 \\
\hline & $12 / 01 / 06$ & 0 & 0 & 0 & 0 \\
\hline & $27 / 01 / 06$ & 0 & 0 & 0 & 0 \\
\hline & $10 / 02 / 06$ & 0 & 0,32 & 0 & 9,52 \\
\hline & $23 / 02 / 06$ & 0,04 & 1,4 & 0 & 4,24 \\
\hline & $05 / 03 / 06$ & 0,03 & 0,7 & 0 & 5,48 \\
\hline & $16 / 03 / 06$ & 2,35 & 2,69 & 0 & 9,72 \\
\hline & $18 / 03 / 06$ & 0,17 & 1,34 & 0,18 & 6,87 \\
\hline & $23 / 03 / 06$ & 0,09 & 0,61 & 0 & 4,97 \\
\hline & 04/04/06 & 0 & 0 & 0 & 63,27 \\
\hline & $21 / 04 / 06$ & 0 & 0 & 0 & 0 \\
\hline & $20 / 05 / 06$ & 0 & 0,32 & 0 & 0 \\
\hline
\end{tabular}

(a) CTDP = conventional soil tillage and planting of the cotton in the direction of the slope; (b) CTCP = conventional tillage and contour planting;(c) $\mathrm{CP}=$ tillage of soil with a disk harrow and a leveling harrow, followed by contour planting; (d) $\mathrm{CoP}=$ tillage by two passes of a leveling harrow followed by contour planting; (e) $\mathrm{MTCP}=$ minimum tillage with contour planting. $\mathrm{NO}_{3}{ }^{-}=$nitrate, $\mathrm{NO}_{2}{ }^{-}=$nitrite, $\mathrm{PO}_{4}{ }^{3-}=$ phosphate, $\mathrm{K}=$ potassium, Treat. = treatment (type of soil tillage system), and D. Samp. $=$ sampling date. 
In Figure $5 \mathrm{~b}$, which shows the CTCP soil tillage system, a high loss $\left(145 \mathrm{~g} \mathrm{ha}^{-1}\right)$ of nitrite $\left(\mathrm{NO}_{2}{ }^{-}\right)$occurred in collection number $12(4 / 21 / 06)$, which corresponds to $93 \%$ of all the $\mathrm{NO}_{2}{ }^{-}$lost in the experimental period. This loss also occurred due to the high concentration of the element in water on this sampling date (Table $2 \mathrm{~b}$ ), which was eight times greater than the concentrations of the previous collections.

The soil management with the mineral fertilizations probably also contributed to this elevated result, especially the topdressing fertilization with urea (Table 1), which was done mechanically under commercial farming conditions. Thus, a failure possibly occurred in the distribution of this nitrogen fertilizer, with a very high amount of urea falling only on the plot with the CTCP treatment. Nitrite $\left(\mathrm{NO}_{2}^{-}\right)$is toxic to most soil microorganisms and rarely accumulates in agricultural soils; however, in conditions that favor the presence of free ammonia $\left(\mathrm{NH}_{3}\right)$, with localized urea fertilization, nitrite accumulation may occur because the bacteria of the Nitrobacter genus are sensitive to urea, and they are the main organisms responsible for the oxidation of nitrite to nitrate (Costa, 2014).

The water losses on the different sampling dates also followed the same trend as the rainfall erosivity index $\left(\mathrm{EI}_{30}\right)$ for the soil tillage systems CTCP, CP, CoP, and MTCP (Figure 5 b, c, d, and e, respectively). Low amounts
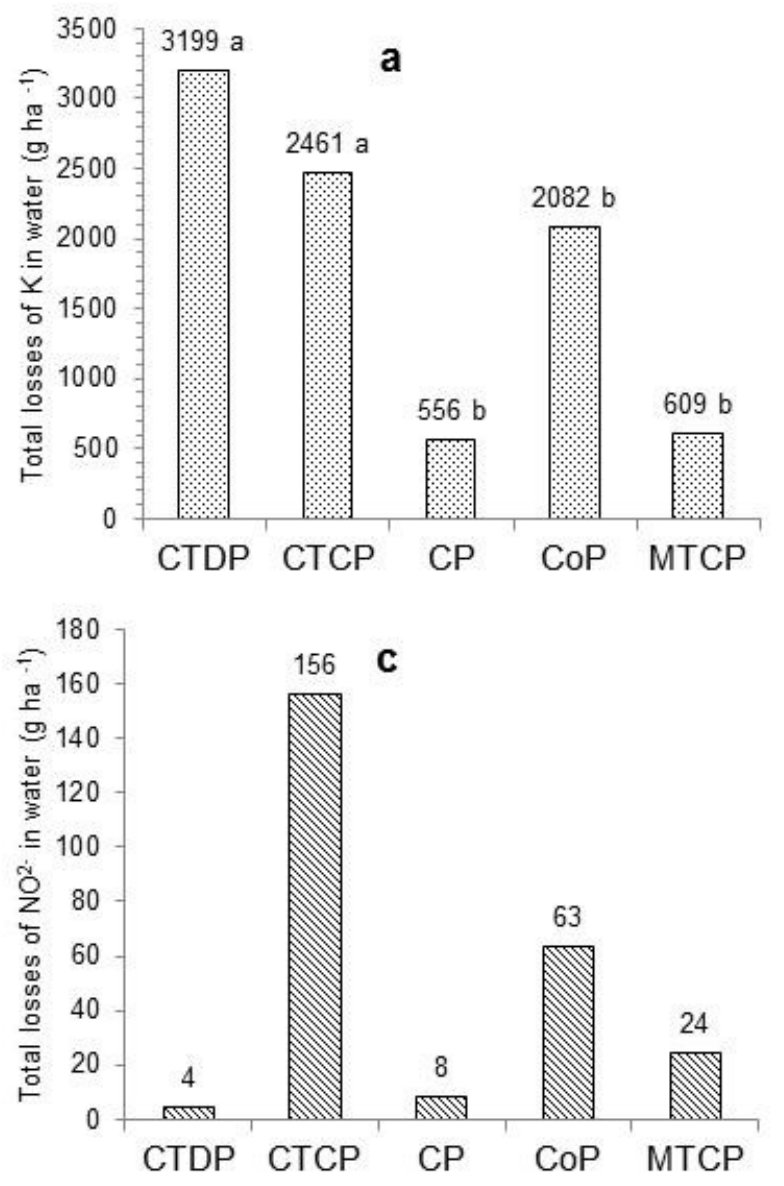

of nutrient losses in water for nitrate $\left(\mathrm{NO}_{2}{ }^{-}\right)$, nitrite $\left(\mathrm{NO}_{3}{ }^{-}\right)$, and phosphate $\left(\mathrm{PO}_{4}{ }^{3-}\right)$ were also observed in these four soil tillage systems, with the $\mathrm{PO}_{4}{ }^{3-}$ results being consistent with those of Barbosa et al. (2009) and Alvarez et al., 2014, who studied the losses of phosphorus in water. For potassium $(\mathrm{K})$, in these four soil tillage systems, higher values were observed for the losses in water via runoff compared to nitrate $\left(\mathrm{NO}_{3}{ }^{-}\right)$, nitrite $\left(\mathrm{NO}_{2}{ }^{-}\right)$, and phosphate $\left(\mathrm{PO}_{4}^{3-}\right)$.

In this study, fitting a model that would express the loss by runoff during the crop cycle of the cotton plant was only possible for potassium $(\mathrm{K})$ - the highest losses of $\mathrm{K}$ in water were observed in the CTDP and CTCP tillage systems, whereas the lowest occurred in the $\mathrm{CP}, \mathrm{CoP}$, and MTCP tillage systems (Figure 6 a). The smallest losses of $\mathrm{K}$ in water were observed in the more conservationist tillage systems and those with greater conservation of the plant cover. These results agree with those found by Gómez et al. (2009) and Dechen et al., 2015, who found the highest losses of $\mathrm{K}$ in water in conventional tillage system compared to treatments that used crops with soil cover, and disagree with the data published by Bosch et al. (2015), who found $\mathrm{K}$ values in the runoff that were similar in conventional (without plant cover) and no-tillage (with plant cover) tillage systems.
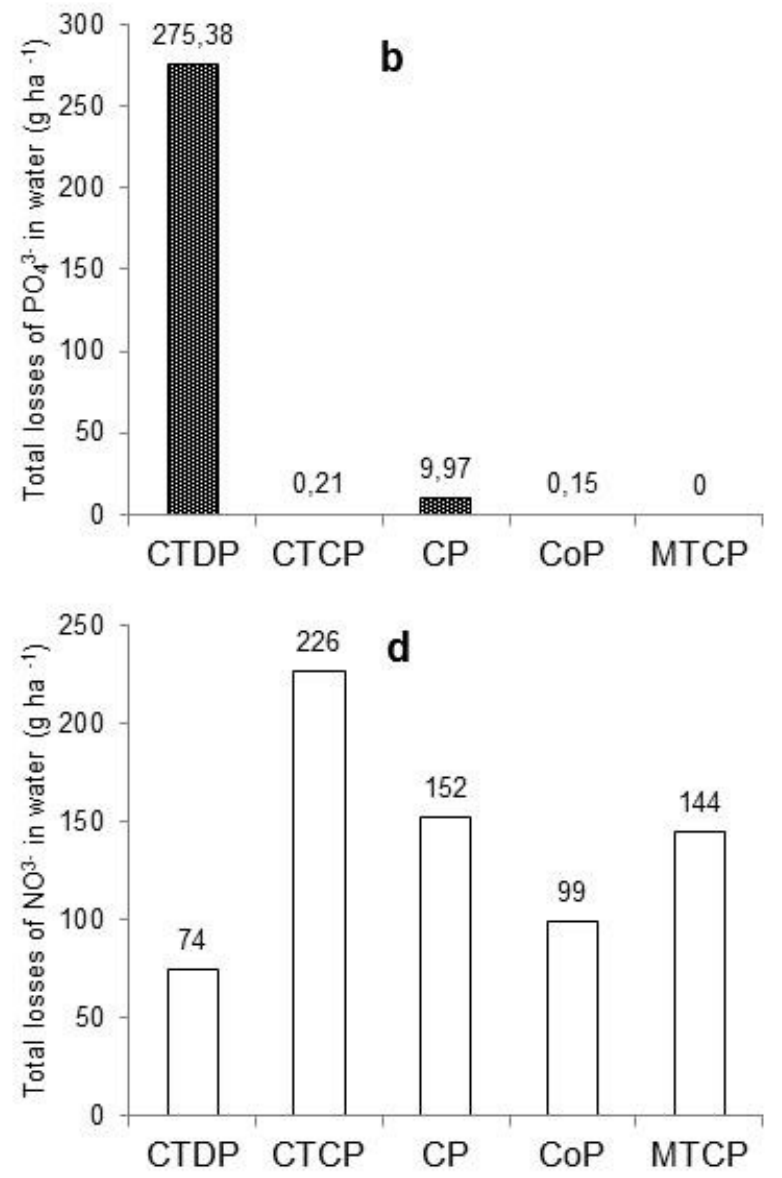

(a) potassium; (b) phosphate; (c) nitrite; (d) nitrate.

$\mathrm{CTDP}=$ conventional soil tillage and cotton planting in the direction of the slope; $\mathrm{CTCP}=$ conventional tillage and contour planting; $\mathrm{CP}=$ tillage of soil with a disk harrow and a leveling harrow, followed by contour planting; CoP = tillage by two passes of a leveling harrow followed by contour planting; and $\mathrm{MTCP}=$ minimum tillage with contour planting. $\mathrm{NO}_{3}^{-}=$nitrate, $\mathrm{NO}_{2}^{-}=$nitrite, $\mathrm{PO}_{4}{ }^{--}=$phosphate, and $\mathrm{K}=$ potassium. Same letters for the total losses of $\mathrm{K}$ in water $\left(\mathrm{g} \mathrm{ha}^{-1}\right)$ do not differ between each other by the identity testing of models $(\mathrm{p}<0.01)$.

FIGURE 6. Total losses of nutrients by laminar runoff, from December 2005 to May 2006. 
The low water erosion losses of the other nutrients studied here- $\mathrm{PO}_{4}{ }^{3-}, \mathrm{NO}_{2}{ }^{-}$, and $\mathrm{NO}_{3}{ }^{-}$- shown in Figures 6 $\mathrm{b}$, c, and d, respectively - can be explained by the low concentrations of nutrients obtained in the runoff (Table 2) compared to the $\mathrm{K}$ concentrations studied here. Guadagnin et al. (2005) also found low concentrations of nitrogen and phosphorus in the losses of such nutrients in water.

For all treatments, the losses of $\mathrm{K}$ in the runoff water were significantly higher than the phosphate losses. These results agree with those of Gómez et al. (2009) also observed losses of water soluble $\mathrm{K}$ that were nearly 5.3 times greater than the losses of $\mathrm{P}$ in water. In this study, a possible explanation for the high losses of potassium in the runoff, compared to the phosphate losses, is that the study was done in a Typical Acric Red-Yellow Latosol with a very clayey texture, where the phosphorus is strongly adsorbed to the sediments (Ker, 1995), together with the fact that $\mathrm{K}$ is more soluble and mobile in the soil compared to $\mathrm{P}$ (Oliveira et al., 2015). From an environmental point of view, the low phosphorus loss in water, combined with the fact that this is a limiting factor for triggering the eutrophication of waters, mean that in this study, such environmental damage to the water resources was reduced due to the class of soil studied (Latosol).

\section{CONCLUSIONS}

The losses of water by runoff obtained in this study were highest for the conventional tillage and planting of cotton in the direction of the slope (CTDP); intermediate for the treatment with conventional soil tillage and contour planting (CTCP), the tillage with two passes of a leveling harrow and contour planting $(\mathrm{CoP})$, and the minimum tillage with contour planting (MTCP); and lowest for the tillage with a disk harrow and a leveling harrow, followed by contour planting $(\mathrm{CP})$.

Potassium (K) was the nutrient that had the highest concentrations and losses in water: the highest values were found in the CTDP and CTCP tillage systems, whereas the lowest were observed for the CP, CoP, and MTCP treatments. The concentrations and the losses by water erosion of phosphate $\left(\mathrm{PO}_{4}{ }^{3-}\right)$, nitrite $\left(\mathrm{NO}_{2}{ }^{-}\right)$, and nitrate $\left(\mathrm{NO}_{3}{ }^{-}\right)$were low in all of the soil tillage systems compared to the losses of $\mathrm{K}$ in this study.

\section{ACKNOWLEDGMENTS}

We acknowledge the Mato Grosso Research Foundation (Fundação de Amparo à Pesquisa do Estado Mato Grosso - FAPEMAT) for assistance in performing this study and the National Council for Scientific and Technological Development (Conselho Nacional de Desenvolvimento Científico e Tecnológico- $\mathrm{CNPq}$ ) for granting the Master's Scholarship to author ${ }^{1}$ of this article.

\section{REFERENCES}

Alvarez JWR, Pellegrini A, Kochem ML, Schaefer GL, Capoane V, Tiecher T, Fornari MR, Santos DR (2014) Erosão hídrica e perda de sedimento, água e nutrientes durante eventos pluviais em duas bacias hidrográficas rurais. Investigación Agraria 16(2):113-123.
Barbosa FT, Bertol I, Luciano RV, Gonzalez AP (2009) Phosphorus losses in water and sediments in runoff of the water erosion in oat and vetch crops seed in contour and downhill. Soil \& Tillage Research 106:22-28. DOI: http://dx.doi.org/10.1016/j.still.2009.09.004

Bertol I (1994) Erosão hídrica em Cambissolo Húmico distrófico sob diferentes preparos do solo e rotação de cultura. Revista Brasileira de Ciência do Solo 18:267-271.

Bertol I, Cogo NP, Schick J, Guadagnin JC, Amaral AJ (2007) Aspectos financeiros relacionados às perdas de nutrientes por erosão hídrica em diferentes sistemas de manejo do solo. Revista Brasileira de Ciência do Solo 31:133-142. DOI: http://dx.doi.org/10.1590/S010006832007000100014

Bertoni J, Lombardi Neto F (1990) Conservação do solo. Piracicaba, Livroceres, 392p.

Bosch DD, Potter TL, Strickland TC, Hubbard RK (2015) Dissolved Nitrogen, Chloride, and Potassium loss from fields in conventional and conservation tillage. American Society of Agricultural and Biological Engineers ASABE 58(6):1559-1571. DOI:

http://dx.doi.org/10.13031/trans.58.11223

Costa AM (2014) Avaliação da influência da salinidade na nitrificação biológica. Dissertação Mestrado, Rio de Janeiro, Universidade Federal do Rio de Janeiro, Escola de Química, 99f.

Dechen SCF, Telles TS, Guimarães MF, Maria IC (2015) Perdas e custos associados à erosão hídrica em função de taxas de cobertura do solo. Bragantia 74(2):224-233.

Gómez JA, Guzma NMG, Ldez JVG (2009) The influence of cover crops and tillage on water and sediment yield, and on nutrient, and organic matter losses in an olive orchard on a sandy loam soil. Soil \& Tillage Research 106:137144. DOI: http://dx.doi.org/10.1016/j.still.2009.04.008

Guadagnin JC, Bertol I, Cassol PC, Amaral AJ (2005) Perdas de solo, água e nitrogênio por erosão hídrica em diferentes sistemas de manejo. Revista Brasileira de Ciência do Solo 29:277-286. DOI: http://dx.doi.org/10.1590/S0100-06832005000200013

Ker JC (1995) Mineralogia, sorção e desorção de fosfato, magnetização e elementos traços de Latossolos do Brasil. Tese D.S., Viçosa, Universidade Federal de Viçosa.

Klimaszyk P, Rzymski P, Piotrowicz R, Joniak T (2015) Contribution of surface runoff from forested areas to the chemistry of a through-flow lake. Environmental Earth Sciences 73:3963-3973. DOI:

http://dx.doi.org/10.1007/s12665-014-3682-y

Leite MHS, Couto EG, Amorim RSS, Lenza CE, Maraschin L (2009) Perdas de solo e nutrientes num Latossolo Vermelho-Amarelo ácrico típico, com diferentes sistemas de preparo e sob chuva natural. Revista Brasileira de Ciência do Solo 33:689-699. DOI: http://dx.doi.org/10.1590/S0100-06832009000300021

Lombardi Neto F (1977) Rainfall erosivity - its distribution and relationship with soil loss at Campinas, Brazil. Mestrado, West Lafayette, Purdue University. 
Luciano RV, Bertol I, Barbosa FT, Vázquez EV, Fabian EL (2009) Perdas de água e solo por erosão hídrica em duas direções de semeadura de aveia e ervilhaca. Revista Brasileira de Ciência do Solo 33:669-676. DOI: http://dx.doi.org/10.1590/S0100-06832009000300019

Marioti J, Bertol I, Ramos JC, Werner RS, Padilha J, Bandeira DH (2013) Erosão hídrica em semeadura direta de milho e soja nas direções da pendente e em contorno ao declive, comparada ao solo sem cultivo e descoberto. Revista Brasileira de Ciência do Solo 37:1361-1371.

Morais LFB, Silva V, Naschenveng TMC, Hardoin PC, Almeida JEL, Weber OLS, Boel E, Durigon V (1991) Índice EI30 e sua relação com o coeficiente de chuva do sudoeste de Mato Grosso. Revista Brasileira de Ciência do Solo 15:339-344.

Munodawafa A (2012) Research on Soil Erosion. In: Godone D, Stanchi S. Quantifying nutrient losses with different sediment fractions under four tillage systems and granitic sandy soils of Zimbabwe. DOI:

http://dx.doi.org/10.5772/3402

Oliveira LC, Bertol I, Barbosa FT, Campos ML, Mecabô Junior M (2015) Perdas De Solo, Água e Nutrientes por Erosão Hídrica em uma Estrada Florestal na Serra Catarinense. Ciência Florestal 25(3):655-665.

Ortiz LL, Range GF, Fernández LIH, Peña MG (2015) Metahemoglobinemia en un lactante por consumo de água con alto contenido de nitratos en Camagüey. Revista Cubana de Higiene y Epidemiología 53(3).

Panachuki E, Bertol I, Sobrinho TA, Oliveira PTS, Rodrigues DBB (2011) Perdas de solo e de água e infiltração de água em Latossolo Vermelho sob sistemas de manejo. Revista Brasileira de Ciência do Solo 35:17771785. DOI: http://dx.doi.org/10.1590/S010006832011000500032
Panachuki E, Santos MAN, Sobrinho DSPTA, Camacho MA, Ontanari R (2015) Soil and water loss in Ultisol of the Cerrado-Pantanal Ecotone under diferente management systems. African Journal of Agricultural Research 10(9):926-932.

Ramos MR, Favaretto N, Dieckow J, Dedeck RA, Vezzani FM, Almeida L, Sperrin M (2014a) Soil, water and nutrient loss under conventional and organic vegetable production managed in small farms versus forest system. Journal of Agriculture and Rural Development in the Tropics and Subtropics 115:31-40.

Ramos JC, Bertol I, Barbosa FT, Marioti J, Werner RS (2014b) Influência das condições de superfície e do Cultivo do solo na erosão hídrica em um Cambissolo húmico. Revista Brasileira de Ciência do Solo 38:15871600. DOI: http://dx.doi.org/10.1590/S010006832014000500024

Tartari DT, Nunes MCM, Santos FAZ, Faria Junior CA, Serafim ME (2012) Perda de solo e água por erosão hídrica em Argissolo sob diferentes densidades de cobertura vegetal. Revista Brasileira de Agroecologia 7(3):85-93.

Vidal TF, Capelo Neto J (2014) Dinâmica de nitrogênio e fósforo em reservatório na região semiárida utilizando balanço de massa. Revista Brasileira de Engenharia Agrícola e Ambiental 18(4). DOI: http://dx.doi.org/10.1590/S1415-43662014000400007

Wischmeier WH, Smith DD (1978) Predicting rainfall erosion losses: A guide to conservation planning. Washington, USDA, 58p. Agricultural Handbook. 